\title{
Analysis of a Solar Cooling System for Climatic Conditions of Five Different Cities of Saudi Arabia
}

\author{
M. Mujahid Rafique ${ }^{1}$, Shafiqur Rehman ${ }^{2, *}$, Aref Lashin ${ }^{3,4}$ and Nassir Al Arifi ${ }^{5}$ \\ 1 Department of Mechanical Engineering, King Fahd University of Petroleum and Minerals, Dhahran 31261, \\ Saudi Arabia; g201303750@kfupm.edu.sa \\ 2 Center for Engineering Research, Research Institute, King Fahd University of Petroleum and Minerals, \\ Dhahran 31261, Saudi Arabia \\ 3 College of Engineering, Petroleum and Natural Gas Engineering Department, King Saud University, \\ P.O. Box 800, Riyadh 11421, Saudi Arabia; aref70@hotmail.com \\ 4 Faculty of Science, Geology Department, Benha University, P.O. Box 13518, Benha 345629, Egypt \\ 5 College of Science, Geology and Geophysics Department, King Saud University, P.O. Box 2455, \\ Riyadh 11451, Saudi Arabia; nalarifi@ksu.edu.sa \\ * Correspondence: srehman@kfupm.edu.sa; Tel.: +966-13-8603802
}

Academic Editor: Kamel Hooman

Received: 8 December 2015; Accepted: 19 January 2016; Published: 27 January 2016

\begin{abstract}
Air high in humidity leads to uncomfortable conditions and promotes the growth of different fungi and bacteria, which may cause health problems. The control of moisture content in the air using traditional air conditioning techniques is not a suitable option due to large consumption of primary energy and hence emission of greenhouse gases. The evaporative cooling technology is a cost effective and eco-friendly alternative but can provide thermal comfort conditions only under low humidity conditions. However, the evaporative cooling method can be used effectively in conjunction with desiccant dehumidifiers for better control of humidity. Such systems can control the temperature and humidity of the air independently and can effectively utilize the low-grade thermal energy resources. In this paper, the theoretical analysis of desiccant based evaporative cooling systems is carried out for five cities in Saudi Arabia (Jeddah, Jazan, Riyadh, Hail, and Dhahran). It has been observed that the coefficient of performance (COP) of the system varies from 0.275 to 0.476 for different locations. The water removal capacity of the desiccant wheel is at its maximum for the climatic conditions of Jazan and at its minimum for Hail. The effect of climatic conditions of five cities on regeneration temperature, air mass flow rate, and potential of solar energy has been evaluated using RET Screen software.
\end{abstract}

Keywords: thermal cooling; desiccant wheel; evaporative cooling; clean technology; energy saving; Saudi Arabia

\section{Introduction}

In order to provide comfortable indoor conditions, cooling requirements should be considered in terms of both the sensible and latent cooling capacities, especially for hot and humid outdoor conditions. The basic requirements for the human comfort provided by the air conditioning system are illustrated in Figure 1 [1]. To control the air humidity using a vapor compression system, the air is cooled below its dew point temperature to extract the moisture and then reheated again to the desired supply temperature, which increases the electricity bill significantly. The heating, ventilating and air conditioning (HVAC) load of the world is estimated to rise $6.2 \%$ per year [2]. It is well known fact that a considerable part of the primary energy is used for air conditioning purposes. Furthermore, it is worthwhile observing that: 
- The most recent standards regarding environmental comfort and indoor air quality (IAQ) impose restrictive limits to indoor relative humidity values.

- Chlorofluorocarbon (CFC) and Hydro Chlorofluorocarbon (HCFC) refrigerant fluids are expected to disappear.

- $\quad$ Electric power peaks need to be reduced.

Therefore, it seems necessary to develop new air conditioning techniques. Thermal air conditioning systems based on chemical dehumidification are characterized by high energy efficiency and low environmental impact. These systems can have profitable results if compared to traditional air conditioning systems [3-6].

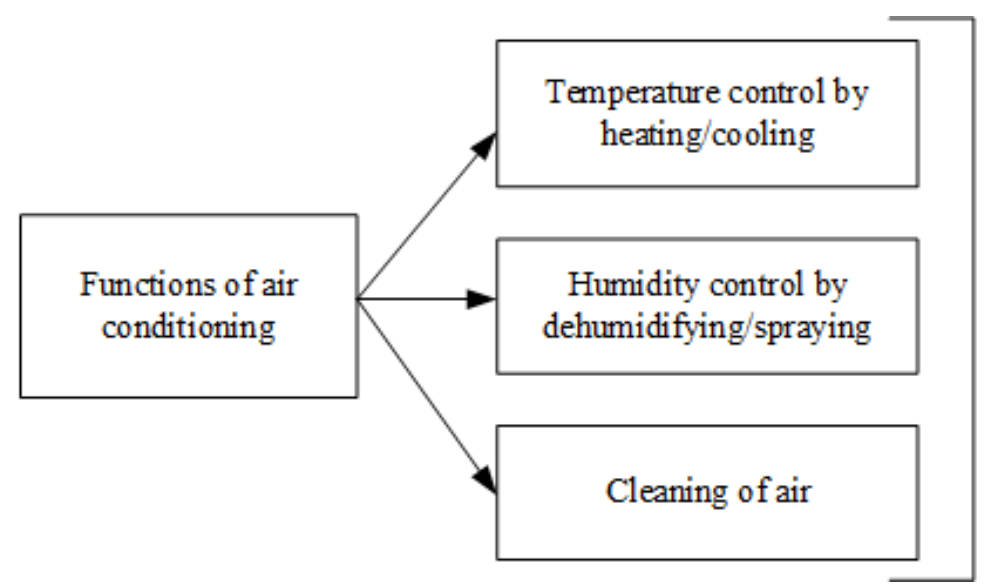

Distribution to conditioned space

Figure 1. The functions of air conditioning.

The humid air has high partial vapor pressure while desiccant materials create an area of lower surface vapor pressure. This difference of vapor pressure causes transfer of moisture from air to the desiccant material [7]. The desiccant material is desired to have a low surface vapor pressure for better dehumidification of the air. The surface vapor pressure of desiccant material increases as it absorbs moisture from the air. Regeneration heat is supplied to keep the desiccant dry and have lower surface vapor pressure. The desiccant material may be solid or liquid. Solid desiccants inserted in a rotary heat exchanger [8], called desiccant wheel (DW) are utilized, especially in HVAC applications.

The idea of desiccant cooling technology was first introduced by Hausen in 1935 [9]. Many inventors like Shipman [10], Fleisher [11], Larriva [12] and Altenkirch [13,14] made efforts to develop desiccant cooling systems for commercial air conditioning using this idea but were not too successful at that time.

The desiccant evaporative cooling systems lead to remarkable reductions in electrical energy consumption as compared to conventional units and also reduce the number of discomfort hours inside the conditioned zone. The costs of energy are almost halved using hybrid desiccant cooling instead of conventional cooling systems alone [15]. Fairey et al. [16] introduced an idea of passive solar desiccant cooling called Desiccant Enhanced Nocturnal Radiation (DESRAD). The system utilizes a hybrid desiccant cooling system integrated in the roof to control both the sensible and latent loads in hot and humid climates. This proposed system had two modes of operation-the night adsorption and the daytime desorption. The desiccant is regenerated during the day by solar heat. Kim and Jeong [17] investigated the solid desiccant and evaporative cooling system based on $100 \%$ outdoor air to observe the thermal and energy performance of the system. Both indirect evaporative cooler (IEC) and direct evaporative cooler (DEC) were utilized in their work. The results showed that this system could save about $74 \%-77 \%$ of total system operating energy as compared to the conventional systems.

Suryawanshi et al. [18] concluded that a two-stage evaporative cooler was 4.5 times more efficient than the conventional system but only in hot and dry climatic conditions. For the hot and humid 
climatic conditions, it could be combined with a desiccant dehumidifier. Mohammad et al. [19] found from the experimental results that an evaporative cooler can be used effectively in conjunction with the desiccant dehumidifier to provide the comfort conditions for the climatic conditions of Kuala Lumpur, Malaysia. Table 1 presents a comparison between desiccant cooling and conventional air conditioning systems to show the significance of desiccant cooling systems [20].

Table 1. Comparison between desiccant cooling system and conventional air conditioning system [20].

\begin{tabular}{lll}
\hline Parameter & Central Air Conditioning System & Desiccant Dehumidification System \\
\hline Cost of Operation & High & Saves about $40 \%$ \\
\hline Driving Source of Energy & Electricity, Natural gas & $\begin{array}{l}\text { Low grade energy e.g., solar energy, } \\
\text { waste heat, etc. }\end{array}$ \\
\hline Humidity Control & Average & Accurate \\
\hline Quality of Indoor Air & Average & Good \\
\hline System Installment & Easy and well-known & Slightly complicated \\
\hline Capacity for Storage of Energy & Average & Good \\
\hline
\end{tabular}

\section{Need of Alternative Energy Systems in Saudi Arabia}

Saudi Arabia lies between $16^{\circ} 21^{\prime} 58^{\prime \prime} \mathrm{N}$ and $32^{\circ} 9^{\prime} 57^{\prime \prime} \mathrm{N}$ latitudes and $34^{\circ} 33^{\prime} 48^{\prime \prime} \mathrm{E}$ and $55^{\circ} 41^{\prime} 29^{\prime \prime} \mathrm{E}$ longitudes. The country occupies about $80 \%$ of the area of the Arabian Peninsula. A great extreme in temperature, humidity and wide seasonal variations exists in the region [21]. The geographical map of Saudi Arabia showing 13 districts and 29 meteorological stations is shown in Figure 2 [22].

Table 2 presents energy statistics for the country along with population and emission of greenhouse gases $\left(\mathrm{CO}_{2}\right)$. The total peak electricity demand in the Kingdom and share of different sectors is shown in Figures 3 and 4 respectively. The residential sector consumes about $53 \%$ of total electricity demand. This share of the residential sector in the Kingdom is a higher proportion as compared to the global average.

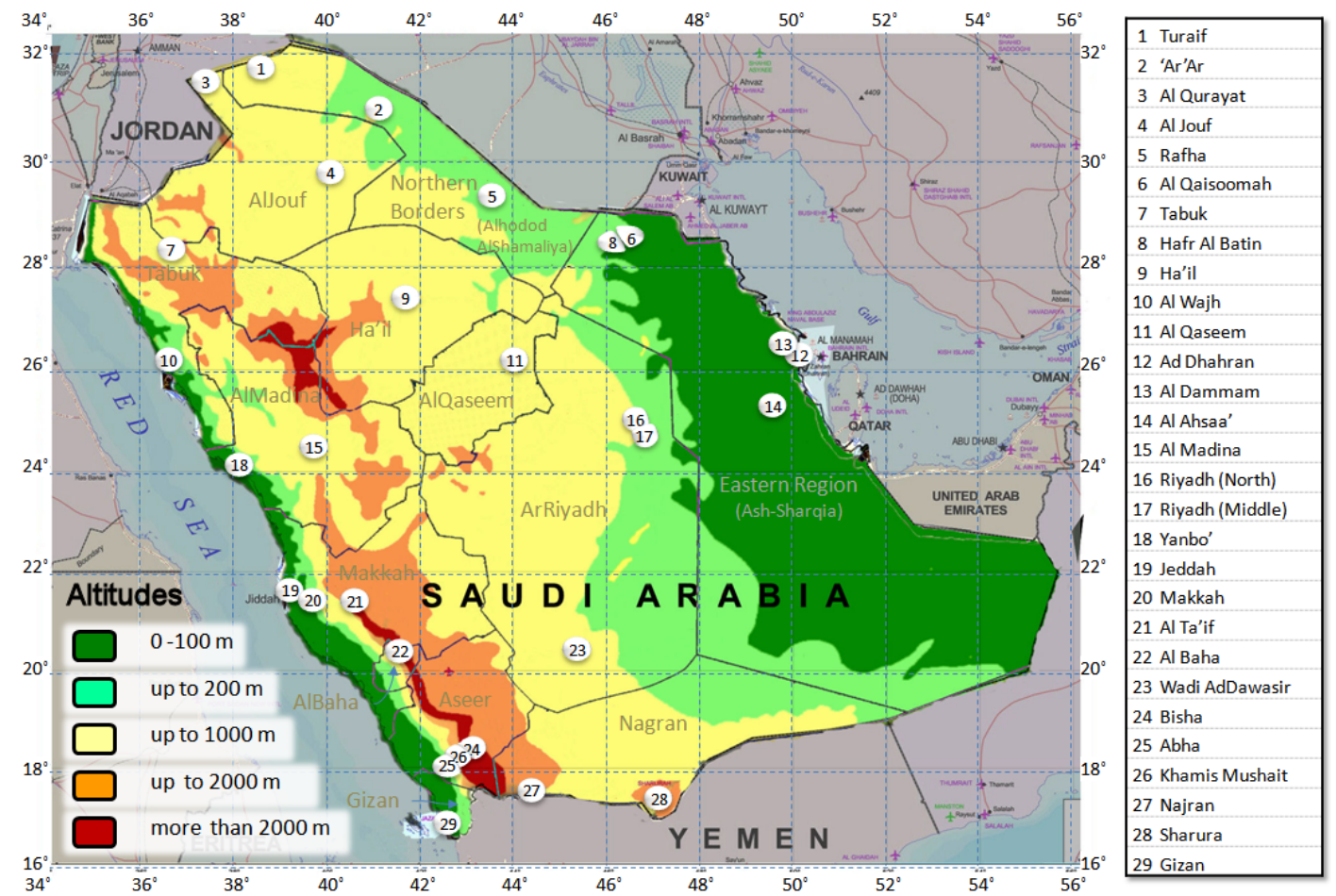

Figure 2. Geographic map of Saudi Arabia [22]. 
Table 2. Energy statistics.

\begin{tabular}{cc}
\hline Parameter & Amount/Value \\
\hline Energy Use Per Capita & $6738.42 \mathrm{~kg}$ of oil equivalent \\
Population & 27.76 million \\
$\mathrm{CO}_{2}$ Emissions Per Capita & 17.04 metric tons \\
\hline
\end{tabular}

Source: World Bank.

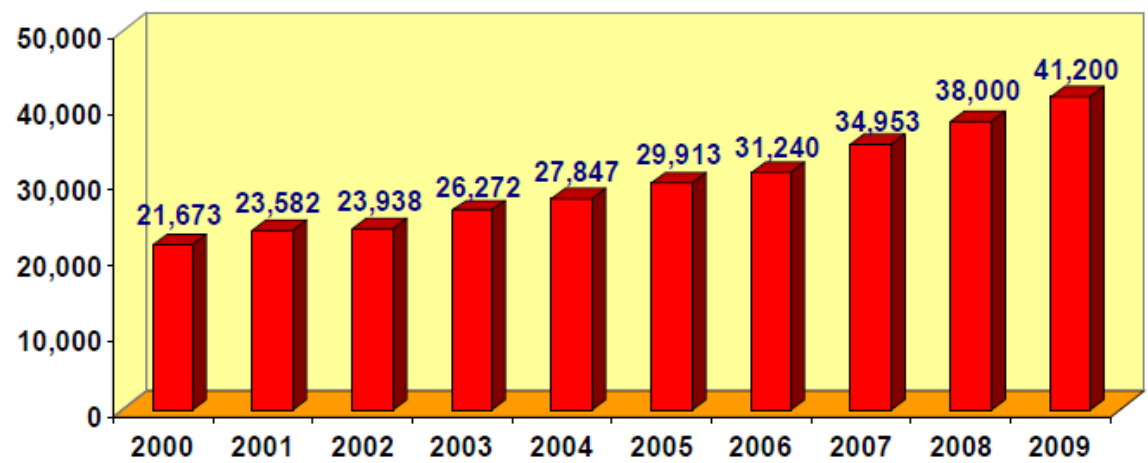

Figure 3. Total peak demand of electricity in the Kingdom (MW).

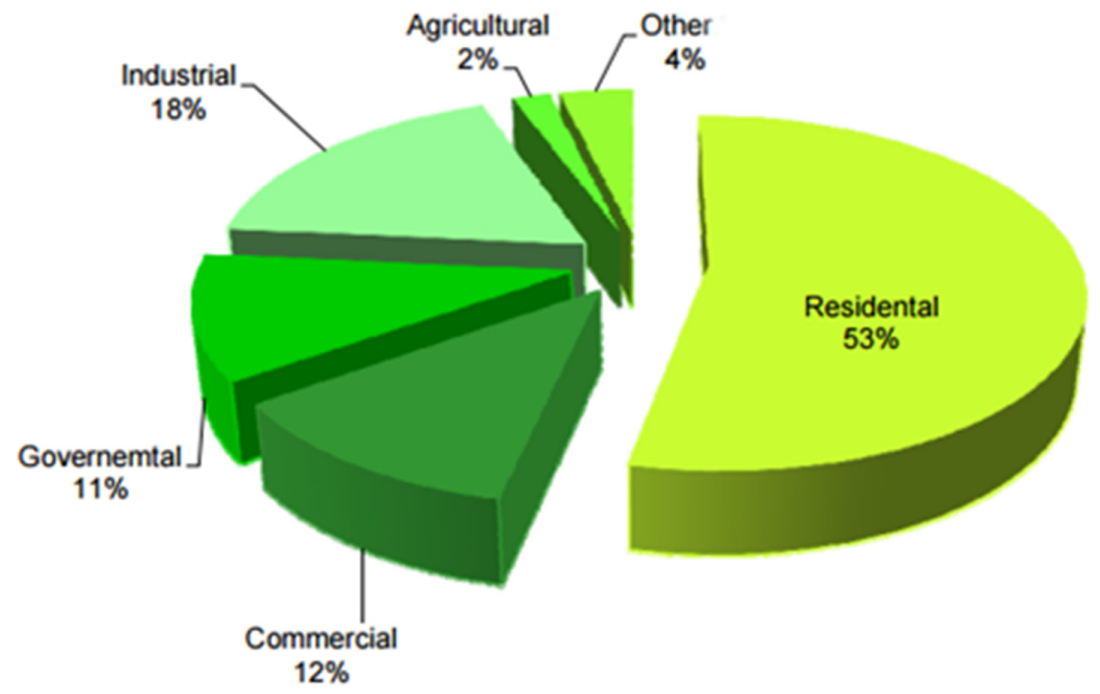

Figure 4. Electricity consumption by sector (Source: Ministry of Water and Electricity).

The Middle East is known for being one of the world's largest suppliers of fossil fuel, but it is often realized that it is also one of the world's biggest consumers of oil. According to the Energy Intelligence Agency (EIA), the growth of oil consumption in the Middle East is greater as compared to the average growth of world (about four times the global growth rate).

The high temperatures in the Kingdom of Saudi Arabia throughout the year make air conditioning a necessity for human comfort. The air conditioning industry shares about $70 \%$ of total consumption of electricity, and this is expected to double by 2030 [23]. Therefore, the need arises for cost-effective and environmentally-friendly cooling techniques that can effectively utilize the alternative energy sources. As mentioned earlier, the desiccant based evaporative cooling is a good and suitable alternative to overcome the fast growth in energy consumption. It can partially fulfill the cooling demands by controlling the humidity and temperature of the building efficiently. The system uses non-ozone depleting refrigerants, which makes it eco-friendly and carbon free as well [24]. 
Saudi Arabia observes high values of global solar radians and long sunshine duration throughout the year $[25,26]$. The solar energy has been proved to be technologically and economically feasible in Saudi Arabia in particular $[27,28]$ and in the region in general. In this paper, a feasibility analysis of a solid desiccant cooling system operating in conjunction with an evaporative cooler is carried out for five cities of Saudi Arabia. The study has been carried out keeping in view the large amount of energy being consumed for air conditioning in Saudi Arabia, and an effort is made to propose a clean and energy efficient cooling system for different parts of the country. The performance of the system has been analyzed considering different parameters such as the air flow rates and regeneration temperature. In addition, the effect of ambient conditions on the performance of the system has been examined.

\section{Solid Desiccant Based Evaporative Cooling System}

Desiccant wheel impregnated with adsorbent materials like silica gel, titanium dioxide, etc., slowly rotates to interact with both streams of process and regeneration air. The desiccant wheel removes moisture from the ambient hot and humid air and temperature of air leaving the desiccant dehumidifier reduced to the desired supply conditions using an evaporative cooler or some other sensible cooling media. The regeneration air is heated up to the desired regeneration temperature to remove the moisture from the desiccant wheel adsorbed by the desiccant from process air stream. The value of regeneration temperature depends on the desiccant material used.

\subsection{System Description}

Figure $5 \mathrm{a}, \mathrm{b}$ shows a desiccant based evaporative cooling system operating on ventilation cycle and its psychrometric processes. The sequence of processes for the process air stream is as follows: (1-2) moisture is removed from the processed air using a desiccant wheel; (2-3) air leaving the desiccant wheel is cooled using heat recovery wheel; (3-4) processed air is further cooled to the comfort conditions using evaporative cooler; (4-5) finally, processed air is supplied to the room.

The operating sequence for the return or regeneration air stream is as follows: (5-6) return air is cooled in the evaporative cooler to its saturation point; (6-7) cooled return air exchanges heat with hot process air in heat recovery wheel; (7-8) air is heated to the required regeneration temperature using solar collector or auxiliary heater; (8-9) finally, hot air passes through the desiccant wheel to regenerate it.

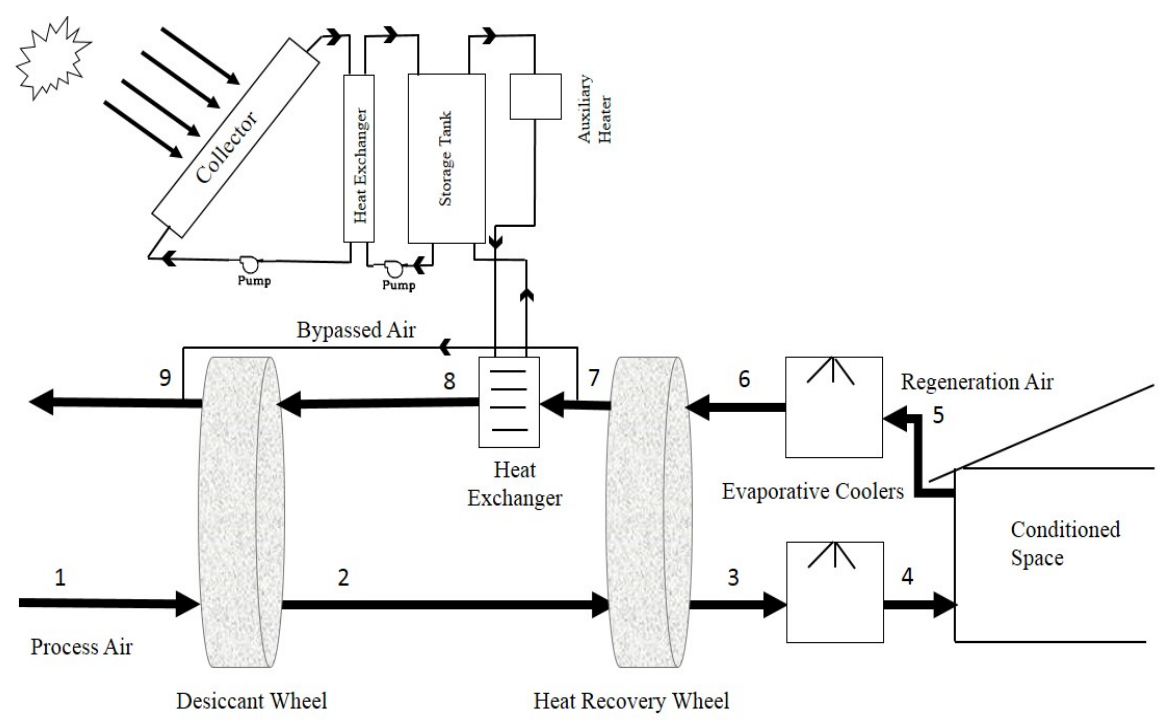

(a)

Figure 5. Cont. 


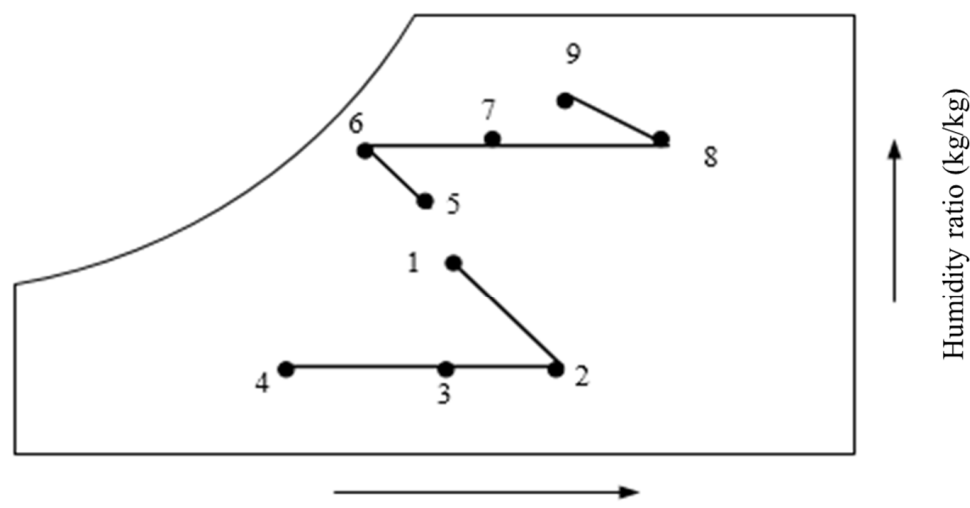

Dry bulb temperature $\left({ }^{\circ} \mathrm{C}\right)$

(b)

Figure 5. (a) Schematic diagram of a desiccant based evaporative cooling system; (b) psychrometric representation of processes.

\subsection{Solar Collector Subsystem}

The required regeneration energy for the solid desiccant system is provided by a solar subsystem. The system components and their configuration are shown in Figure 5. The system compromises an array of solar collectors with area of $50 \mathrm{~m}^{2}$ and a $50 \%$ propylene glycol/water solution at an average flow rate of $0.015 \mathrm{~kg} / \mathrm{s} \cdot \mathrm{m}^{2}$ of collector area [29] as the working fluid to transfer the energy using a heat exchanger. An auxiliary heater is also installed in series with a hot water storage tank for continuous operation of the system in the absence of sunlight. For the recommended storage volume of $50-100 \mathrm{~L} / \mathrm{m}^{2}$ of a collector area, an average value of $0.075 \mathrm{~m}^{3} / \mathrm{m}^{2}$ of collector area is chosen. General expression for collector efficiency and useful energy gain is given as [30]:

$$
\begin{aligned}
\eta_{c} & =\frac{Q_{u}}{A_{c}-G}=F_{R}(\tau \alpha)-F_{R}\left(T_{i}-T_{a}\right) \\
Q_{u} & =F_{R} A_{c}[G(\tau \alpha)]-F_{R} U_{L} A_{c}\left(T_{i}-T_{a}\right)
\end{aligned}
$$

where $F_{R}(\tau \alpha)=0.777$ and $F_{R} U_{L}=15.8424 \mathrm{~W} / \mathrm{m}^{2}$.

\subsection{Solar Fraction}

In solar cooling applications, solar collectors convert solar radiations into thermal energy. The backup heating source is provided with the solar collector to supplement the insufficient thermal energy provided by the solar collectors in cloudy weathers. The percentage of solar energy provided by the solar collectors is known as the solar fraction (SF) and given as [31]:

$$
S F=\frac{Q_{u}}{Q_{t}}
$$

\section{Performance Parameters}

The system's coefficient of performance (COP) is given as the ratio of the system cooling load and heat needed for regeneration:

$$
\mathrm{COP}=\frac{\text { Cooling Load }}{\text { Input heat }}
$$

where the cooling load of the cycle is given as:

$$
Q_{c}=\dot{m}_{p}\left(h_{1}-h_{4}\right)
$$


The desiccant wheel regeneration heat is given by:

$$
Q_{r}=\dot{m}_{r}\left(h_{8}-h_{7}\right)
$$

The total capacity of moisture removal for the system is represented as the moisture absorbed from the air by the desiccant wheel and is calculated as [32]:

$$
M_{p}=\dot{m}_{p}\left(\omega_{1}-\omega_{2}\right)
$$

\section{Results and Discussion}

A code has been developed in an Engineering Equation Solver (EES) using mathematical model equations, and performance of the system is investigated. The performance curve of desiccant wheel, psychrometric chart, and mathematical equations developed by Camargo et al. [33] have been used for computing the temperatures and humidity ratio of the air at different points in the cycle. The built in function of the Engineering Equation Solver (EES) is used to obtain the thermodynamic properties of the air. In addition, it is assumed that effectiveness of evaporative coolers and heat recovery wheel varies from $75 \%$ to $95 \%$.

Five different cities of Saudi Arabia have been selected to analyze the performance of the system for the climatic conditions of each city. Table 3 summarizes the geographical data of five cities used in the present analysis. The weather data has been obtained from RET Screen software [34] and listed in Table 4 along with desired indoor supply conditions. The obtained value of average COP at regeneration temperature of $120^{\circ} \mathrm{C}$ have also been presented and compared in Table 4 . The COP of the system is largely influenced by inlet air temperature and humidity ratio. It is observed that the system can operate with the highest COP of 0.475 for the climatic conditions of Jazan while the lowest COP of the system is found for Hail.

Figure 6 shows the variation of COP with the effectiveness of the evaporative cooler for different cities. The effectiveness of evaporative cooler is varied from $75 \%$ to $95 \%$ to observe its effect on COP of the system. It can be observed from the Figure 6 that COP of the system increases with the increase in effectiveness of evaporative cooler for all cities under study. About a $30 \%-50 \%$ increase in COP can be achieved by increasing about $15 \%$ effectiveness of the direct evaporative cooler.

Table 3. Geographic data of study related cities.

\begin{tabular}{cccccc}
\hline Location & Jeddah & Jazan & Riyadh & Hail & Dhahran \\
\hline Latitudes (ø) & 21.7 & 16.9 & 24.7 & 27.4 & 26.3 \\
Longitude & 39.2 & 42.6 & 46.7 & 41.7 & 50.2 \\
Elevation (m) & 17 & 7 & 620 & 1002 & 17 \\
Wind speed (m/s) & 3.6 & 3.3 & 0.5 & 3.2 & 4.4 \\
\hline
\end{tabular}

Table 4. Average outdoor conditions, supply conditions, and coefficient of performance of a desiccant

\begin{tabular}{|c|c|c|c|c|c|c|c|}
\hline \multirow[b]{2}{*}{$\begin{array}{l}\text { Name of } \\
\text { Cities }\end{array}$} & \multicolumn{3}{|c|}{ Outdoor Air } & \multicolumn{3}{|c|}{ Supply Air } & \multirow[b]{2}{*}{$\begin{array}{c}\text { COP } \\
\left(\mathrm{T}_{\text {reg }}=120^{\circ} \mathrm{C}\right)\end{array}$} \\
\hline & $\begin{array}{c}\text { Dry Bulb } \\
\text { Temperature } \\
\left({ }^{\circ} \mathrm{C}\right)\end{array}$ & $\begin{array}{c}\text { Wet Bulb } \\
\text { Temperature } \\
\left({ }^{\circ} \mathrm{C}\right)\end{array}$ & $\begin{array}{c}\text { Specific } \\
\text { Humidity } \\
\text { (g/kg) }\end{array}$ & $\begin{array}{c}\text { Dry Bulb } \\
\text { Temperature } \\
\left({ }^{\circ} \mathrm{C}\right)\end{array}$ & $\begin{array}{c}\text { Wet Bulb } \\
\text { Temperature } \\
\left({ }^{\circ} \mathrm{C}\right)\end{array}$ & $\begin{array}{c}\text { Specific } \\
\text { Humidity } \\
\text { (g/kg) }\end{array}$ & \\
\hline Jeddah & 32.7 & 24.8 & 16.76 & 19.85 & 16.05 & 10.30 & 0.447 \\
\hline Jazan & 33.6 & 26.93 & 20.06 & 20.33 & 18.55 & 11.42 & 0.476 \\
\hline Riyadh & 34.8 & 25.13 & 19.50 & 19.80 & 17.90 & 10.43 & 0.387 \\
\hline Hail & 32.6 & 22.23 & 15.93 & 18.33 & 16.42 & 9.46 & 0.275 \\
\hline Dhahran & 36.1 & 26.53 & 18.29 & 21.77 & 18.22 & 10.22 & 0.463 \\
\hline
\end{tabular}
cooling cycle for different cities of Kingdom Saudi Arabia (KSA). 


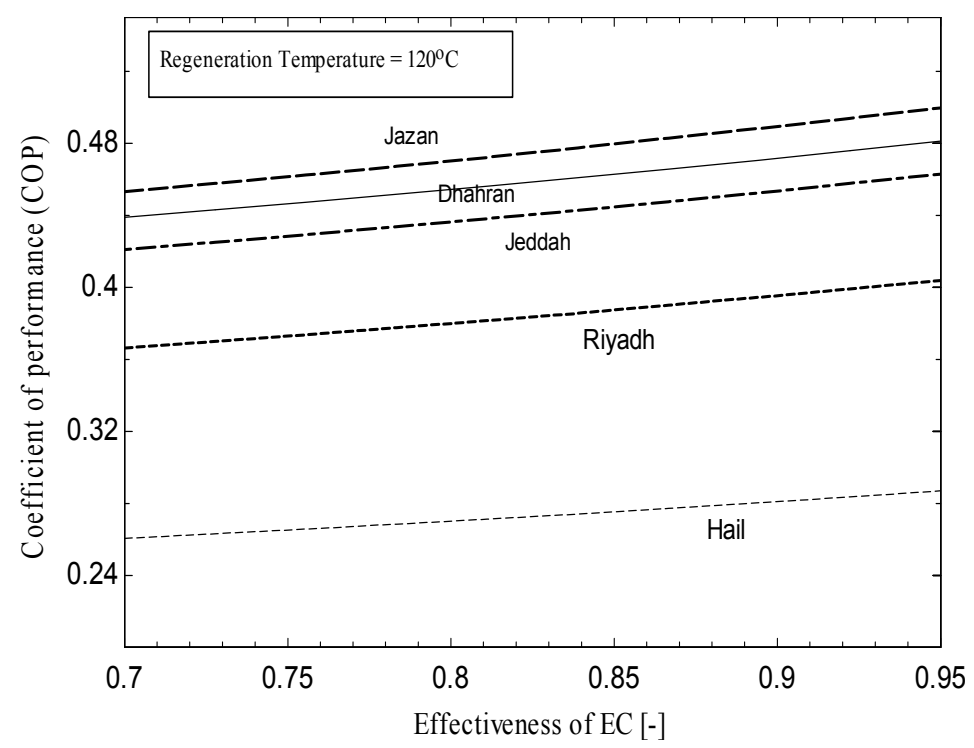

Figure 6. Variation of coefficient of performance with effectiveness of evaporative cooler.

The partial vapor pressure is the governing factor for the mass transfer between processed air and desiccant surface. As the inlet air humidity ratio increases, the partial vapor pressure of water vapor in the air also increases. This, in turn, increases the difference between the partial vapor pressure of the inlet air stream and the desiccant surface. Ultimately, this increases the moisture removing capacity of desiccant. The temperature of air at the exit of the desiccant wheel increases as the temperature of the ambient air increases. This increase in the difference of temperature increases the difference in enthalpy of the air across the rotary dehumidifier. This increased difference in enthalpy causes an increase in the cooling capacity of the system.

The flow rate of regeneration air and temperature has a strong impact on the performance of the desiccant cooling system. The performance improvement of the system is expected at lower regeneration temperature and air mass flow rate because both of these factors have a direct effect on required input thermal energy. The thermal energy input increases with the increase in regeneration temperature, which will decrease the overall COP of the system.

The variation of $\mathrm{COP}$ with regeneration temperature and the ratio of regeneration and processed air flow rate are shown in Figures 7 and 8 respectively. The regeneration temperature is varied from 90 to $180^{\circ} \mathrm{C}$ to observe its effect on the system performance. It is observed that, as the regeneration temperature increases, the $\mathrm{COP}$ of the system decreases as illustrated in Figure 7. Similarly, an increase in the air flow rate ratio tends to decrease the COP of the system. The decrease in the system COP due to an increase in both the regeneration temperature and the mass flow rate ratio is due to the increase in required regeneration heat. Although the higher value of regeneration temperature will make the moisture removal process faster, at the same time this higher value of temperature will dry-up the desiccant wheel before the completion of regeneration period. Hence, some added energy will be wasted and will not be utilized during moisture removal. The increase in regeneration temperature and regeneration to processed air flow rate ratio (or increase in regeneration air flow rate) will increase the required regeneration heat, which, in turn, will decrease the COP of the system. Figure 9 presents the moisture removal rate from the processed air for different cities. It is observed that the water removal rate is at its maximum for Jazan and at its minimum for Hail. 


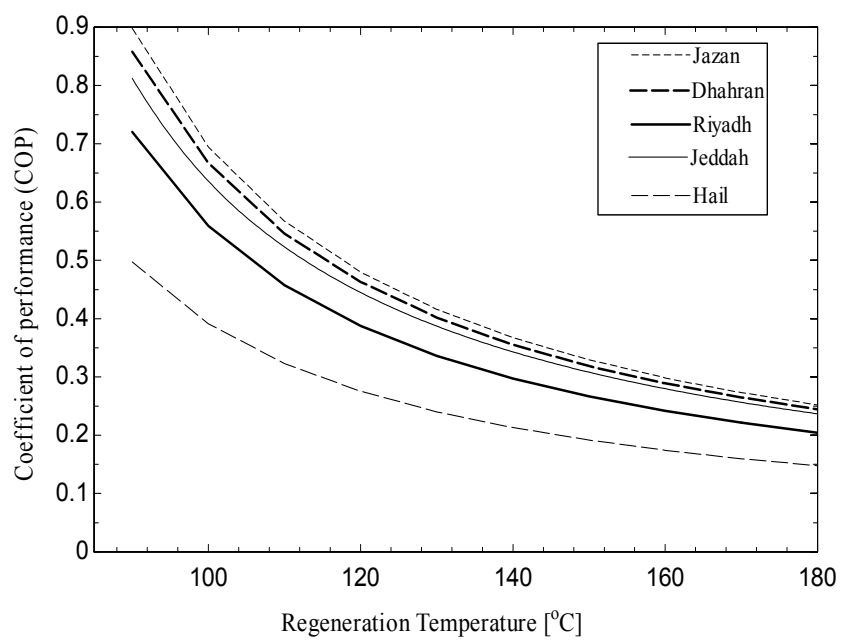

Figure 7. Variation of coefficient of performance with regeneration temperature.

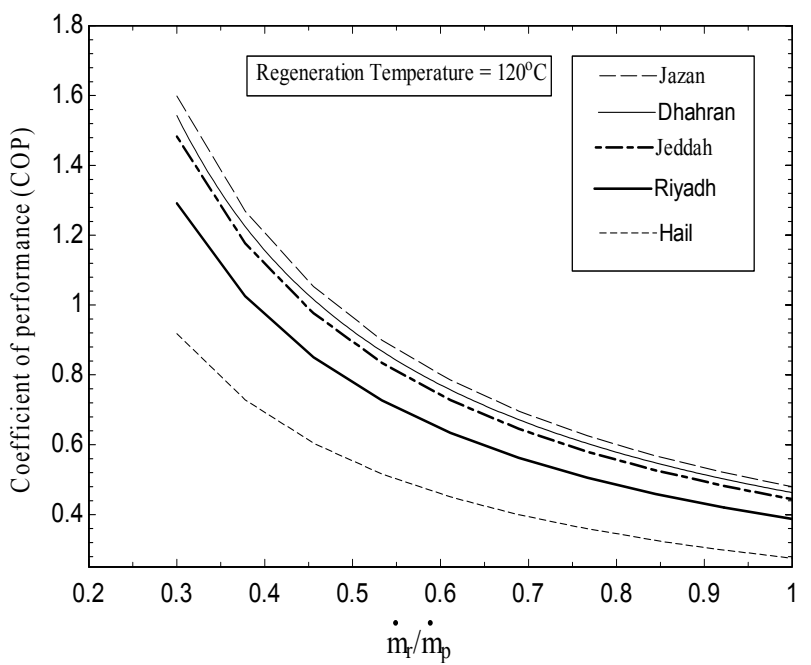

Figure 8. Variation of coefficient of performance with ratio of mass flow rates.

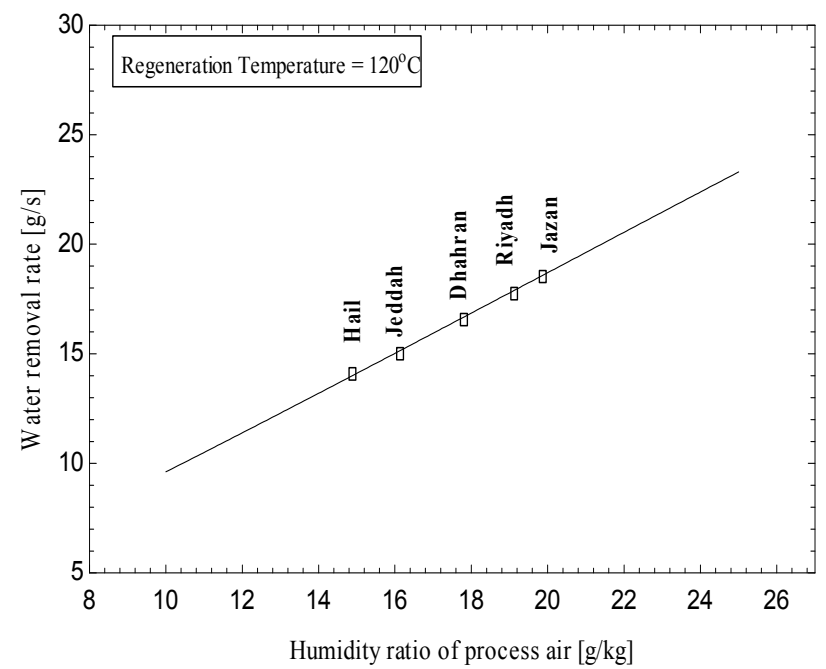

Figure 9. Variation water removal rate with inlet air humidity ratio. 
Monthly variation of daily solar radiation on horizontal surfaces is presented in Figure 10 for all of the selected cities. On an annual basis, Jazan experiences the maximum daily solar radiations $\left(6.24 \mathrm{kWh} / \mathrm{m}^{2} / \mathrm{d}\right)$ while Riyadh receives the minimum solar radiations $\left(5.13 \mathrm{kWh} / \mathrm{m}^{2} / \mathrm{d}\right)$. The results indicate that Dhahran receives maximum solar radiations for the month of June but throughout the year Jazan receives maximum solar radiations. It also shows that the Jeddah region has the advantage of higher solar radiations in winter season as well.

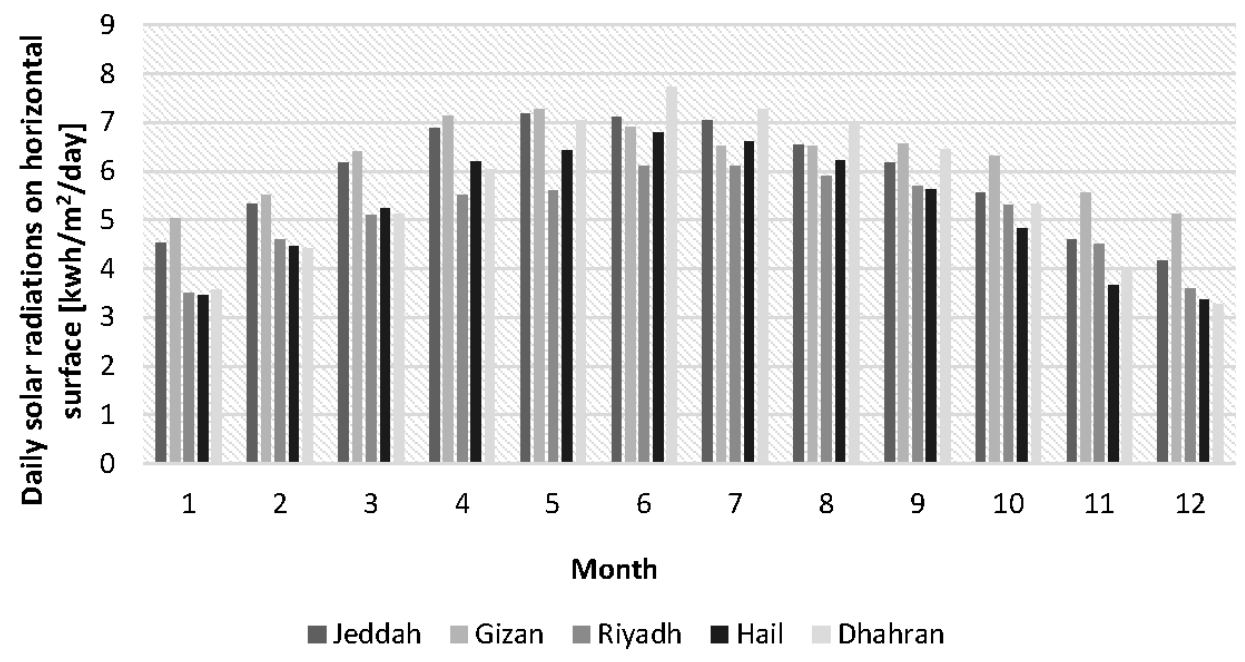

Figure 10. Monthly variation of daily solar radiation on horizontal surfaces.

\section{Conclusions}

The desiccant based evaporative cooling system is relatively a new technology and is a good alternative for conventional mechanical vapor compression air conditioning systems, especially in hot and humid climatic conditions.

In this paper, a theoretical analysis of desiccant based evaporative cooling units has been carried out for five different cities of Saudi Arabia. It can be concluded that ambient temperature and humidity affects the performance of desiccant based evaporative cooling systems. Five different locations (Jeddah, Jazan, Riyadh, Hail, and Dhahran) with hot and humid climatic conditions were found to have different potentials of desiccant based evaporative cooling units. The results of the study can be summarized as follows:

- It has been found that the effective control of dehumidification capacity can be achieved by using desiccant based evaporative cooling systems in hot and humid climatic conditions.

- For Jazan, the potential of the proposed system is found to be high to provide the thermal comfort conditions compared to other cities.

- It has also been observed that an increase of $15 \%$ in evaporative cooler effectiveness resulted in about $15 \%-25 \%$ increase in COP of the system depending on the location.

- An increase in regeneration temperature and ratio of air flow rate caused a decrease in the system COP.

- The effectiveness of the desiccant wheel increases with the increase in ambient air humidity ratio.

- Furthermore, the results showed that moisture removal rate is the maximum for the climatic conditions of Jazan.

- Among all five cities, Jazan was found to have the maximum solar energy potential for the whole year while Riyadh has the minimum.

- The lower value of regeneration temperature is beneficial for the performance of the system, as it defines the required input energy. 
For better coefficient of performance of the overall system, the desiccant material should have a lower temperature of regeneration, which is a key factor for future research. The desiccant based evaporative cooling technology can first be targeted for commercial buildings rather than residential buildings because of high energy and financial payback in hot and humid climatic conditions.

Acknowledgments: The authors would like to thank King Fahd University of Petroleum and Minerals in Dhahran, Saudi Arabia, for funding the research reported in this paper. Furthermore, the partial support of the Deanship of Scientific Research at King Saud University, Riyadh, Saudi Arabia through the international research group project number IRG14-36 is greatly appreciated by Aref Lashin and Nassir Al Arifi.

Author Contributions: This paper is a result of the full collaboration of all the authors. All authors have participated in preparing the research from the beginning to the end, such as establishing research design, method and analysis. All authors discussed and finalized the analysis results to prepare manuscript according to the progress of research.

Conflicts of Interest: The authors declare no conflict of interest.

\section{Nomenclatures}

$\begin{array}{ll}E_{F a n} & \text { fan electrical power }(\mathrm{kW}) \\ h & \text { specific enthalpy }(\mathrm{kJ} / \mathrm{kg}) \\ M & \text { moisture removal rate }(\mathrm{g} / \mathrm{s}) \\ \dot{m} & \text { mass flow rate }(\mathrm{kg} / \mathrm{s}) \\ \dot{m}_{w} & \text { mass flow rate of water }(\mathrm{kg} / \mathrm{s}) \\ Q_{c} & \text { cooling load }(\mathrm{kW}) \\ Q_{r} & \text { regeneration heat }(\mathrm{kW}) \\ T_{r e g} & \text { regeneration temperature }\left({ }^{\circ} \mathrm{C}\right)\end{array}$

\section{Greek Letters}

$\begin{array}{ll}\omega & \text { humidity ratio }(\mathrm{g} / \mathrm{kg}) \\ \varepsilon & \text { effectiveness }(-)\end{array}$

\section{Subscripts}

$\begin{array}{ll}\text { a } & \text { Ambient } \\ \text { DW } & \text { desiccant wheel } \\ \text { DCS } & \text { desiccant cooling system } \\ \text { H } & \text { Heater } \\ \text { HRW } & \text { heat recovery wheel } \\ \text { EC } & \text { evaporative cooler } \\ \text { p } & \text { Process } \\ \text { r } & \text { Regeneration } \\ \text { v } & \text { Vapor }\end{array}$

\section{References}

1. Ameen, A. The challenges of air-conditioning in Tropical and Humid Tropical climates. In Proceedings of the International Conference on Mechanical Engineering (ICME 2005), Dhaka, Bangladesh, 28-30 December 2005.

2. Rafique, M.M. A statistical analysis of desiccant dehumidifier for air conditioning application. Int. J. Hybrid Inf. Technol. 2015, 8, 245-256. [CrossRef]

3. Meckler, M. Desiccant-assisted air conditioner improves IAQ and comfort. Heat. Pip. Air Cond. 1994, $66,75-84$.

4. McGahey, K. New commercial applications for desiccant-based cooling. ASHRAE J. 1998, 40, 41-45.

5. Gagliano, A.; Patania, F.; Nocera, F.; Galesi, A. Performance assessment of a solar assisted desiccant cooling system. Therm. Sci. 2014, 18, 563-576. [CrossRef] 
6. Stefano, E.; Tiberi, V. Dimensioning and efficiency evaluation of hybrid solar systems for energy production. Therm. Sci. 2008, 12, 127-138.

7. Angrisani, G.; Roselli, C.; Sasso, M.; Tariello, F. Assessment of energy, environmental and economic performance of a solar desiccant cooling system with different collector types. Energies 2014, 7, 6741-6764. [CrossRef]

8. Bulck, E. The Design of Dehumidifiers for Use in Desiccant Cooling and Dehumidification Systems, Desiccant Cooling and Dehumidification; ASHRAE: Atlanta, GA, USA, 1992; pp. 118-126.

9. Pesaran, A.A.; Penney, T.R.; Czanderna, A.W. Desiccant Cooling: State-of-the-Art Assessment; Technical Report No. NREL/TP-254-4147; National Renewable Energy Laboratory: Golden, CO, USA, 1992.

10. Shipman, B.C. Air Cooling and Conditioning Apparatus and System. U.S. Patent 2,058,042, 10 April 1936.

11. Fleisher, W.L. Adsorption System of Air Conditioning. U.S. Patent 2,147,248, 14 February 1939.

12. Larriva, G.A. Air Conditioning System and Apparatus Therefor. U.S. Patent 4,612,019, 16 December 1941.

13. Altenkirch, E. Separating and Cooling Apparatus. U.S. Patent 2,233,189, 25 February 1941.

14. Altenkirch, E. Air Conditioning. U.S. Patent 2,344,384, 10 June 1944.

15. Maclaine-Cross, I.L. Proposal for a desiccant air conditioning system. ASHRAE Trans. 1988, 94, 1997-2009.

16. Fairey, P.; Kerestecioglu, A.; Vieira, R. Analytical Investigation of the Desiccant Enhanced Nocturnal Radiation Cooling Concepts; Final Technical Report No. FSEC-CR-152-86; Florida Solar Energy Center: Cape Canaveral, FL, USA, 1986.

17. Kim, M.; Jeong, J. Development of Desiccant and Evaporative Cooling Based 100\% Outdoor System. In Proceedings of the 2013 Architectural Engineering Conference, State College, PA, USA, 3-5 April 2013; pp. 506-515.

18. Suryawanshi, S.D.; Chordia, T.M.; Nenwani, N.; Bawaskar, H.; Yambal, S. Efficient technique of air conditioning. In Proceedings of the World Congress on Engineering, London, UK, 6-8 July 2011; Volume III.

19. Mohammad, A.T.; Mat, S.B.; Sulaiman, M.Y.; Sopian, K. Experimental performance of a direct evaporative cooler operating in Kuala Lumpur. Int. J. Therm. Environ. Eng. 2013, 6, 15-20.

20. Jiang, Y.; Li, Z.; Chen, X.L.; Liu, X.H. Liquid desiccant air conditioning system and its applications. Heat Vent. Air Cond. 2004, 34, 88-98.

21. AQUASTAT. FAO's Information System on Water and Agriculture, Climate Information Tool. Available online: http://www.fao.org/nr/water/aquastat/countries/saudi_arabia/index.stm (accessed on 21 December 2014).

22. Albakry, A.; Alsaleem, I.; Elbeishi, M. Geography of the Kingdom of Saudi Arabia and some other Countries, 3rd ed.; Saudi Ministry of Education: Riyadh, Saudi Arabia, 2010. Available online: http://www.moe.gov.sa (accessed on 28 December 2014).

23. Saleh, A.A. Deputy Minister of Water and Electricity, ahead of the First Saudi HVAC Conference, Al-Faisaliah Hotel, Riyadh, Saudi Arabia, 11-13 February 2013. Available online: http://www.saudigazette.com.sa/ (accessed on 9 January 2015).

24. Rafique, M.M.; Gandhidasan, P.; Rehman, S.; Al-Hadhrami, L.M. A review on desiccant based evaporative cooling systems. Renew. Sustain. Energy Rev. 2015, 45, 145-159. [CrossRef]

25. Rehman, S.; Bader, M.A.; Moallem, S.A. Cost of solar energy generated using PV panels. Renew. Sustain. Energy Rev. 2007, 11, 1843-1857. [CrossRef]

26. Mohandes, M.; Rehman, S. Estimation of sunshine duration in Saudi Arabia. J. Renew. Sustain. Energy $2013,5$. [CrossRef]

27. Rehman, S.; El-Amin, I. Study of a solar pv/wind/diesel hybrid power system for a remotely located population near Arar, Saudi Arabia. Energy Explor. Exploit. 2015, 33, 591-620. [CrossRef]

28. Rehman, S.; Sahin, A.Z. Performance comparison of diesel and solar photovoltaic power systems for water pumping in Saudi Arabia. Int. J. Green Energy 2015, 12, 702-713. [CrossRef]

29. Duffie, J.; Beckman, W. Solar Engineering of Thermal Process; Wiley: New York, NY, USA, 1991.

30. Klein, K. A Transient System Simulation Program, Version 13.1; Engineering Experiment Station Report; University of Wiscosin-Madison, Solar Energy Laboratory: Madison, WI, USA, 1991.

31. Baniyounes, A.M.; Gang, L.; Rasul, M.G.; Khan, M. Analysis of solar desiccant cooling system for an institutional building in subtropical Queensland, Australia. Renew. Sustain. Energy Rev. 2012, 16, 6423-6431. [CrossRef] 
32. Daou, K.; Wang, R.Z.; Xia, Z.Z. Desiccant cooling air conditioning: A review. Renew. Sustain. Energy Rev. 2006, 10, 55-77. [CrossRef]

33. Camargo, J.R.; Godoy, E.; Ebinuma, C.D. An evaporative and desiccant cooling system for air conditioning in humid climates. J. Braz. Soc. Mech. Sci. Eng. 1995, 27, 1-16. [CrossRef]

34. NASA. A NASA Satellite-Derived Global Meteorology and Surface Solar Energy Climatology Website for RETScreen Parameter Inputs. Available online: https:/ / eosweb.larc.nasa.gov/sse/RETScreen/ (accessed on 11 January 2015).

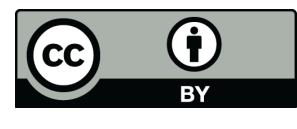

(C) 2016 by the authors; licensee MDPI, Basel, Switzerland. This article is an open access article distributed under the terms and conditions of the Creative Commons by Attribution (CC-BY) license (http://creativecommons.org/licenses/by/4.0/). 